\title{
COMPARISON OF KINETIC MODELS FOR BIOGAS PRODUCTION RATE FROM SAW DUST
}

\author{
Manjula Das Ghatak ${ }^{1}$, P. Mahanta ${ }^{2}$ \\ ${ }^{1}$ Research Scholar, Department of Mechanical Engineering, IIT Guwahati, Guwahati, Assam, 781036, India \\ ${ }^{2}$ Professor, Department of Mechanical Engineering, IIT Guwahati, Guwahati, Assam, 781036, India
}

\begin{abstract}
In this study the effects of temperature on anaerobic co-digestion of saw dust with cattle dung is investigated. It also simulates the biogas production from saw dust with cattle dung at various temperatures. Results showed that high temperature could improve the anaerobic digestion and hence increase the biogas production rates. The operating temperatures used in this study were $35^{\circ} \mathrm{C}$, $45^{\circ} \mathrm{C}$, and $55^{\circ} \mathrm{C}$. Modelling study revealed that exponential plot simulated better in both ascending and descending limb at all the three temperatures. However in ascending limb exponential plot was better for biogas production at $55^{\circ} \mathrm{C}$ and $35^{\circ} \mathrm{C}$ whereas in descending limb exponential plot was better for biogas production at $45^{\circ} \mathrm{C}$. Gaussian plot had higher correlation at $35^{\circ} \mathrm{C}$ compared to other temperatures. Logistic growth model and modified Gompertz plot showed better correlation of cumulative biogas production than exponential rise to maximum plot for all the temperatures.
\end{abstract}

Keywords: anaerobic digestion, biogas production, kinetic model, simulation, co-digestion $* * *$

\section{INTRODUCTION}

Biogas is a type of bio-fuel which is produced from anaerobic digestion of biodegradable materials such as biomass, manures, sewage, municipal waste, green waste, plant material and energy crops.Anaerobic digestion mainly take place at either mesophilic $\left(25^{\circ} \mathrm{C}-40^{\circ} \mathrm{C}\right)$ or thermophilic temperatures $\left(45^{\circ} \mathrm{C}-60^{\circ} \mathrm{C}\right)$ although it can take place at psychrophilic condition $\left(12^{\circ} \mathrm{C}-30^{\circ} \mathrm{C}\right)$ too [Usman et. al, 2012]. Garba, 1996 have found from his experiment that at thermophilic temperature biogas production from lignocellulosic material was the maximum. Previously several researcher like Hashimoto et.al (1981), Varel (1980) etc. have found higher digestion rate, improved solid setting and higher destruction of pathogen in the thermophilic temperature. So, for design of biogas generation, temperature is a very important parameter. Various studies have been carried out by different researcher in the recent past to optimize the biogas yield by anaerobic digestion technology. Several methods are employed to improve the biodigester efficiency and biogas yield like using stirrer [Hamdi M., 1991], co-digesting with other substrates [Somayaji and Khanna, 1994], increasing temperature of digestate [Carlos and John, 2013].

This study focuses on the effect of temperature on biogas production from saw dust which is a lignocellulosic biomass co-digested with cattle dung. For this purpose biogas production rates at different temperatures were modelled using linear, exponential and Gaussian equations. In addition to that cumulative biogas production was simulated using logistic growth model, exponential rise to maximum and modified Gompertz plots.

\section{MATERIALS AND METHOD}

The biomass was collected locally, cleaned and dried for 5 to 6 hour to remove the superficial moisture. After drying the biomass was ball milled and strained through IS sieves of size $0.355 \mathrm{~mm}$. The undersized particles were used as feed material for the anaerobic digestion.

Total solid and volatile matter were determined following standard test methods ASTM E1756-08, and E87282(Reapproved 2006) respectively. Carbon and Nitrogen content of the biomasses were determined by a high resolution Scanning Electron Microscope (SEM) (Make: Carl Zeiss, Model: LEO $1430 \mathrm{VP}$ ) with an attachment of energy dispersive X-ray (EDX) system (Make: Oxford, UK). Fibre constituent analysis was done by using Goering and Van Soest (1970) method and lignin content was determined by the $72 \%$ sulphuric acid method [Lequerica et. al, 1984].

Table 1: Characteristics of Saw Dust and Cattle Dung (Dry Weight Basis)

\begin{tabular}{|l|l|l|}
\hline & $\begin{array}{l}\text { Saw } \\
\text { Dust }\end{array}$ & Cattle Dung \\
\hline Total Solid (\%) & 86.77 & 19.02 \\
\hline Volatile Solids (\%) & 82.79 & 66.2 \\
\hline Carbon (\%) & 63.17 & 35 \\
\hline Nitrogen (\%) & 0.77 & 1.6 \\
\hline C:N ratio & 82.03 & 21.8 \\
\hline Hemicellulose (\%) & 2 & 2.3 \\
\hline Cellulose (\%) & 51 & 4.7 \\
\hline Lignin (\%) & 30.1 & 2.7 \\
\hline Lignin/cellulose ratio & 0.59 & 0.574 \\
\hline
\end{tabular}


Table 1 presents the results of the characterization of the lignocellulosic biomass on dry weight basis. Total solid (TS) of all the biomass was found to be $86.77 \%$ and that of cattle dung was $19.02 \%$. The $\mathrm{C}: \mathrm{N}$ ratio of the biomass was calculated to be $82.03: 1$, whereas that of cattle dung was 21.8:1. Hills and Roberts, 1981 reported that the performance of digesters containing dairy manure and field crop residues is the maximum when the $\mathrm{C}: \mathrm{N}$ ratio of the feed mixtures was between 25 to $30: 1$ and total solid of the slurry was $8 \%$. Budiyono et al., 2010 stated that TSs content of 7.4 and $9.2 \%$ in cattle dung exhibit the best performance for digestibility. Mahanta et al., 2004 reported that for cattle dung at $35^{\circ} \mathrm{C}$ temperature maximum gas production was obtained with $8 \%$ total solid. Many researchers had testified previously about co-digestion of animal manures with various crop residues [Somayaji and Khanna, 1994, Lehtomaki et. al, 2006]. That is why the biomass was mixed with cattle dung and tap water in such a manner so that their C:N ratio come between 25-30:1 ratio and the total solid of the slurry become $9 \%$. In the present case $25 \%$ biomass and $75 \%$ fresh cattle dung was used in the mixture and water was added to the mixtures in 1:3 ratios respectively. From the fiber analysis it was seen that saw dust is having lignin content of $30.1 \%$ and lignin to cellulose ratio 0.59 which is quite near to the value of cattle dung. From the characterization of the biomass it was observed that the biomass have fairly good amount of volatile matter $(82.79 \%)$ indicating fairly good potentiality to generate biogas.

\section{EXPERIMENTAL SET-UP AND PROCEDURE}

The schematic diagram of the experimental set-up is shown in Fig. 1. It consists of a laboratory bio-digester made of borosilicate glass of capacity $1000 \mathrm{ml}$ with air tight rubber cork fitted into its opening. Thermometer and copper tube were fitted through the rubber cork for measuring the slurry temperature and fitting the connecting tube. The other end of the connecting tube was passed through a $500 \mathrm{ml}$ solution bottle containing brine solution. Thus, the biogas produced in the biodigester by the anaerobic digestion process was delivered through the connecting tube to the solution bottle containing brine. The pressure of the biogas produced caused displacement of the brine solution which is then collected in a $200 \mathrm{ml}$ beaker placed on the other side of the solution bottle. The amount of solution collected in the beaker represented the amount of biogas produced in the biodigester. A sampling port was provided through the cork fitted with a valve to take out sample from time to time testing of sample for total solid, volatile solid and $\mathrm{pH}$.

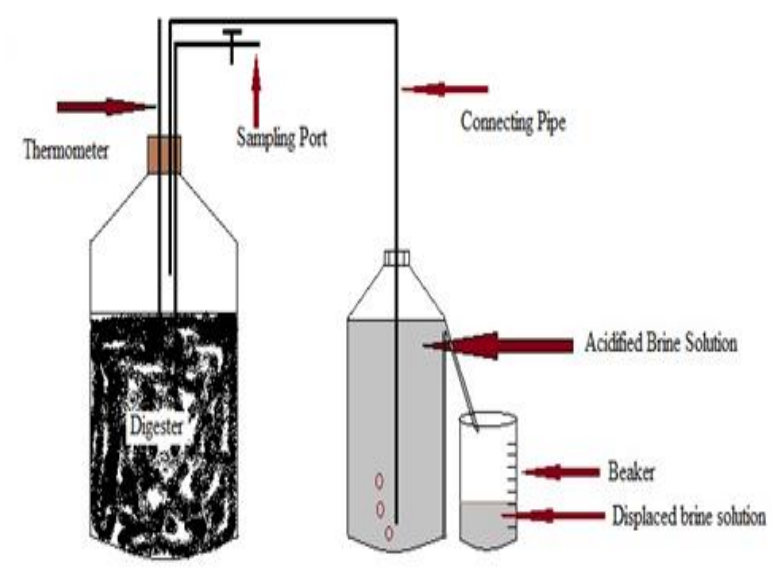

Fig. 1.Schematic Diagram of Experimental Set-Up [Das Ghatak and Mahanta, 2013]

A weighing balance was used to measure the required mass of cattle dung and biomasses. The mercury-in-glass thermometer (range $-10^{\circ} \mathrm{C}$ to $110^{\circ} \mathrm{C}$ ) fitted to the biodigester through the cork was used to measure the daily temperature of the slurry and a digital $\mathrm{pH}$ meter was used to determine the $\mathrm{pH}$ of the fermentation slurry. The constant temperatures of the digesters were maintained by putting the digesters in the water bath at fixed temperature.

The feed material used in this research was saw dust mixed with cattle dung in 1.3 ratio. The feedstock was filled upto $90 \%$ of the $1000 \mathrm{ml}$ borosilicate bottle and was kept in water bath where constant temperature $35^{\circ} \mathrm{C}, 45^{\circ} \mathrm{C}$ and $55^{\circ} \mathrm{C}$ respectively was maintained using thermostat to study the effect of temperature on biogas production rate. Each biomass was mixed with cattle dung in 1:3 ratios and water was added to the mixture in 1:3 ratios to make the total solid $9 \%$. The temperature of the feedstock was measured twice a day with the help of the thermometer fitted through the cork. The biogas productions were monitored daily and measured every five days by means of water displacement method. The lab-scale experiment was carried out for 50 hydraulic retention days until biogas production reduced significantly. It was found that the biogas production was very slow at the beginning and at the end of observation. This is because the biogas production in batch condition directly corresponds to specific growth rate of methanogenic bacteria in biodigesters [Budiyono et.al 2010, Nopharatana et.al, 2007].

\section{BIOGAS PRODUCTION SIMULATION}

The study of the biogas production kinetics for the description and evaluation of methanogenesis was carried out by fitting the experimental data of biogas production to various kinetic equations. Biogas production rates of saw dust co-digested with cattle dung was simulated using linear, exponential and Gaussian plots. The linear equation of the biogas production rate in the ascending and descending limb can be expressed by the equation given below (Kumar et. al, 2004; Lo et. al, 2010). It is assumed that biogas production rate will increase linearly with increase in time and after 
reaching a maximum point after sometime it would decrease linearly to zero with increase in time.

$$
y=a+b T
$$

where, $\mathrm{y}$ =biogas production rate in $\mathrm{ml} / \mathrm{gm} / \mathrm{day}$; $\mathrm{T}=$ time in day for digestion; a $(\mathrm{ml} / \mathrm{gm} /$ day $)$ and $\mathrm{b}(\mathrm{ml} / \mathrm{gm} /$ day 2$)$ are the constants obtained from the intercept and slope of the graph of $\mathrm{y}$ vs T. For the ascending limb, b is positive and it is negative for the descending limb.

The exponential plot for the ascending and descending limb can be presented by the equation (2) [De Gionnis et al.,2009). Here it is assumed that biogas production rate will increase exponentially with increase in time and after reaching the high point it would decrease to zero exponentially with increase in time.

$$
y=a+b \exp (c T)
$$

where, $\mathrm{y}=$ biogas production rate $(\mathrm{ml} / \mathrm{gm} /$ day $) ; \mathrm{T}=$ time needed for digestion (days); $a, b=$ constants $(\mathrm{ml} / \mathrm{gm} /$ day $) ; \mathrm{c}=$ constant (1/day). For the ascending limb, $\mathrm{c}$ is positive and it is negative for the descending limb.

The Gaussian equation shown in Eq. (3) can be applied to simulate biogas production rates including both ascending and descending limb, assuming that biogas production rates would follow the normal distribution over the hydraulic retention time.

$$
y=a \exp \left[-0.5\left(\frac{T-T_{0}}{b}\right)^{2}\right]
$$

where, $\mathrm{y}=$ biogas production rate $(\mathrm{ml} / \mathrm{gm} /$ day $)$ at time $\mathrm{T}$; $\mathrm{T}=$ time needed for digestion (days); $\mathrm{a}(\mathrm{ml} / \mathrm{gm} /$ day) and $\mathrm{b}$ (day) are the constants; $\mathrm{T}_{0}=$ time where the maximum biogas production rate took place.

In addition, cumulative biogas production was simulated using logistic growth model, exponential rise to maximum and modified Gompertz equation. Logistic growth equation is shown in Eq. (4).

$$
y=\frac{a}{1+b \exp (-k T)}
$$

where, $\mathrm{y}=$ Cumulative biogas production $(\mathrm{ml} / \mathrm{gm}) ; \mathrm{k}=$ kinetic rate constant (1/day); T=HRT (Days); a, b are the constants. Exponential rise to maximum is presenred in Eq. (5) [De Gioannis et. al, 2009; Lo et. al, 2010].

$$
y=A(1-\exp (-k T))
$$

Modified Gompertz equation is modified form of the Gompertz equation which is commonly used to simulate the cumulative biogas production [Lo et. al, 2010]. The modified Gompertz equation is (Nopharatana et. al, 2007; Yusuf et.al,2011;Budiyono et.al,2010;Lo et.al,2010) can be presented as follows:

$$
y=A \exp \left\{-\exp \left[\frac{\mu_{m} e}{A}(\lambda-T)+1\right]\right\}
$$

Where, $\mathrm{P}$ is the cumulative of the specific biogas production $(\mathrm{ml} / \mathrm{gm}), \mathrm{A}$ is the biogas production potential $(\mathrm{ml} / \mathrm{gm}), \mathrm{U}$ is the maximum biogas production rate $(\mathrm{ml} / \mathrm{gm} /$ day $), \lambda$ is the lag phase period or the minimum time required to produce biogas (day).

Analysis of the experimental data was performed in MSexcel using the solver feature by non-linear regression.

\section{RESULTS AND DISCUSSION}

This research was carried out to study the influence of temperature on the kinetics of biogas production. The investigation was performed at three different temperatures viz. $35^{\circ} \mathrm{C}, 45^{\circ} \mathrm{C}$ and $55^{\circ} \mathrm{C}$ respectively in $1000 \mathrm{ml}$ volume digesters. The working volumes of the biodigesters were maintained at $900 \mathrm{ml}$ volume and ran under controlled temperature. The substrate considered here is saw dust mixed with fresh cattle dung in 1:3 ratio. Water was added to the mixture in 1:3 ratio thus making the total solid around $9 \%$. The cumulative biogas production was observed for 50 days HRT. The experimental data was analyzed using non linear regression for determining the kinetic constants.

Biogas production rate and accumulation from saw dust and cattle dung mixture were presented in Fig.2. The experiments were carried out at three different temperatures $35^{\circ} \mathrm{C}, 45^{\circ} \mathrm{C}$ and $55^{\circ} \mathrm{C}$. Maximum biogas production rate occurred at about 25 days for all the three cases. Maximum biogas production rate was in the order of biogas production at $55^{\circ} \mathrm{C}>35^{\circ} \mathrm{C}>45^{\circ} \mathrm{C}$. On the other hand cumulative biogas production from the saw dust and cattle mixture was also found to be highest at $55^{\circ} \mathrm{C}$ followed by $35^{\circ} \mathrm{C}$ and $45^{\circ} \mathrm{C}$ respectively. It is obviously observed that maximum biogas production rate was enhanced by the thermophilic methanogenic bacteria at $55^{\circ} \mathrm{C}$ and mesophilic methanogenic bacteria at $35^{\circ} \mathrm{C}$, whereas at $45^{\circ} \mathrm{C}$, the action of the methanogenic bacteria is not that effective. 


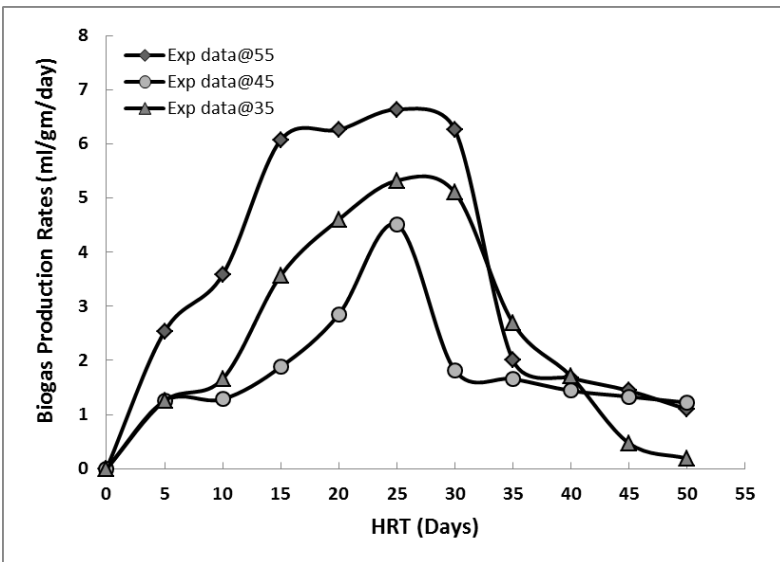

(a)

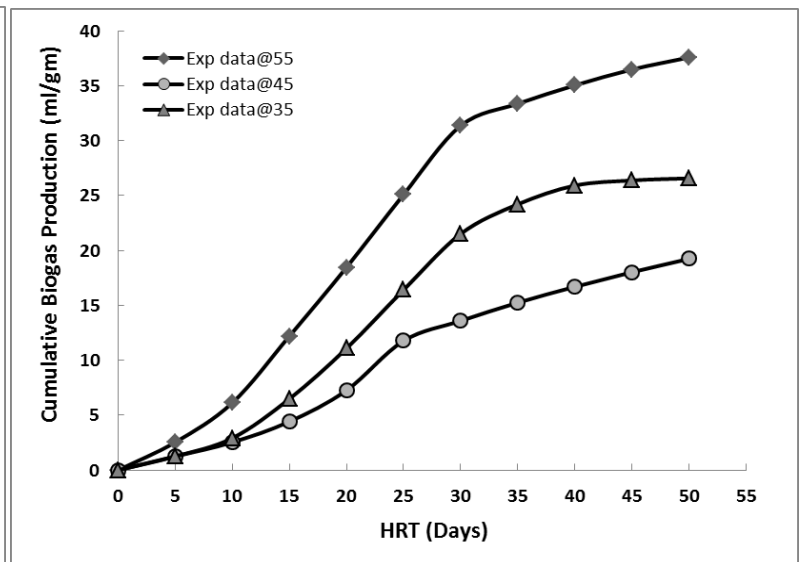

(b)

Fig. 2 Biogas production rates (a) and cumulative biogas production (b) from saw dust and cattle dung mixture at $55^{\circ} \mathrm{C}, 45^{\circ} \mathrm{C}$ and $35^{\circ} \mathrm{C}$.
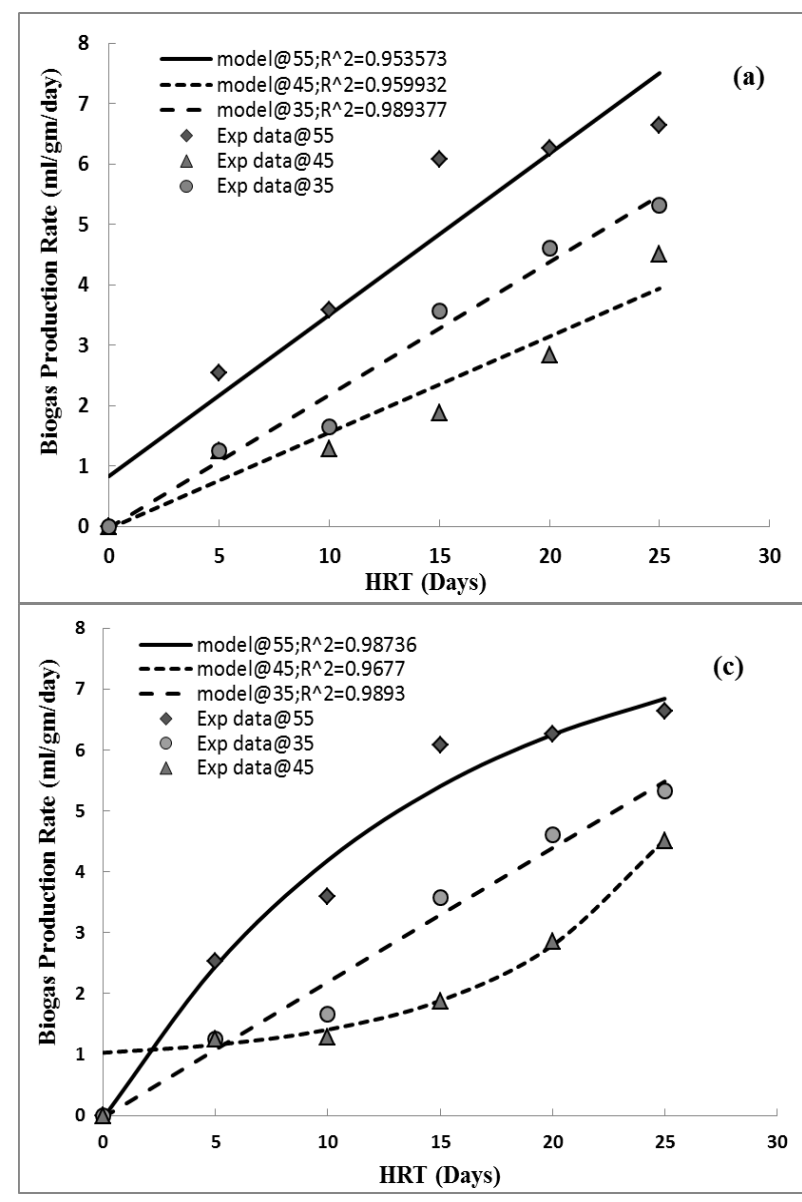
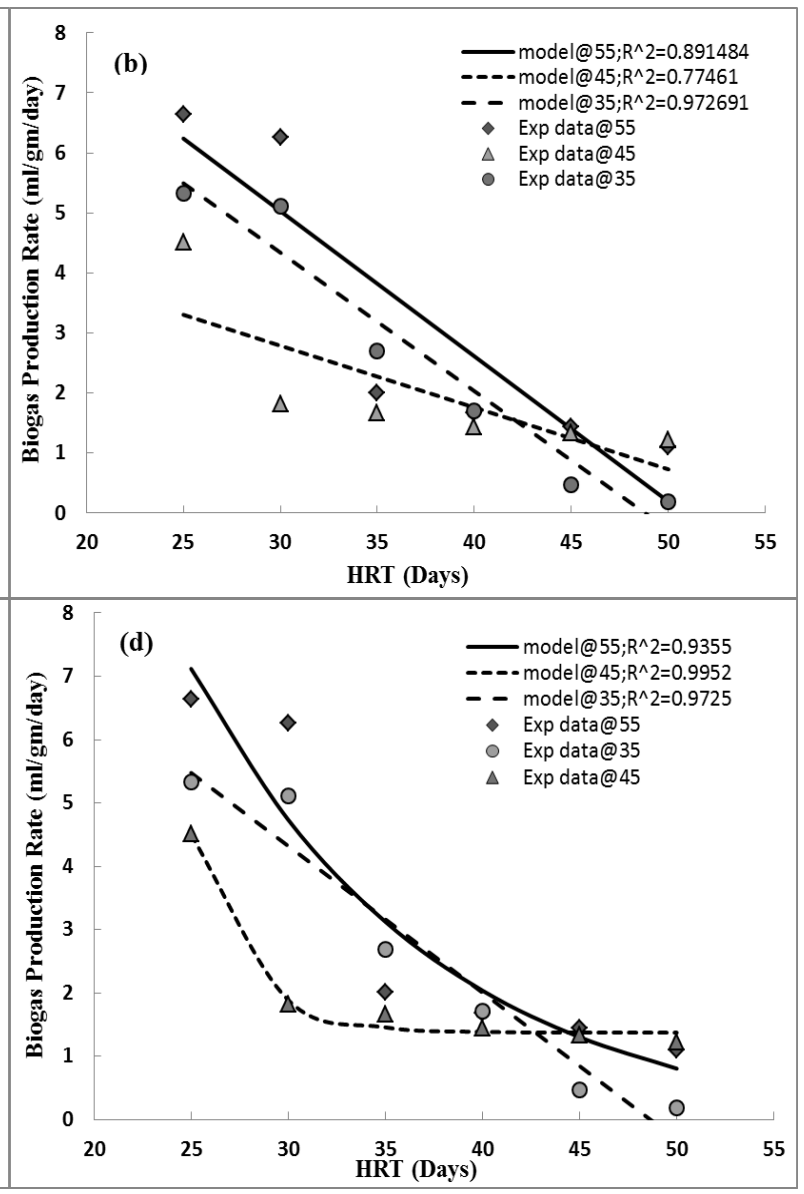

Fig. 3 Linear plots of biogas production rates from saw dust and cattle dung mixture at $55^{\circ} \mathrm{C}, 45^{\circ} \mathrm{C}$ and $35^{\circ} \mathrm{C}$ temperatures in ascending limb (a) and Descending limb (b). Exponential plots of biogas production rates from saw dust and cattle dung mixture at $55^{\circ} \mathrm{C}, 45^{\circ} \mathrm{C}$ and $35^{\circ} \mathrm{C}$ temperatures in ascending limb (c) and Descending limb (d). 


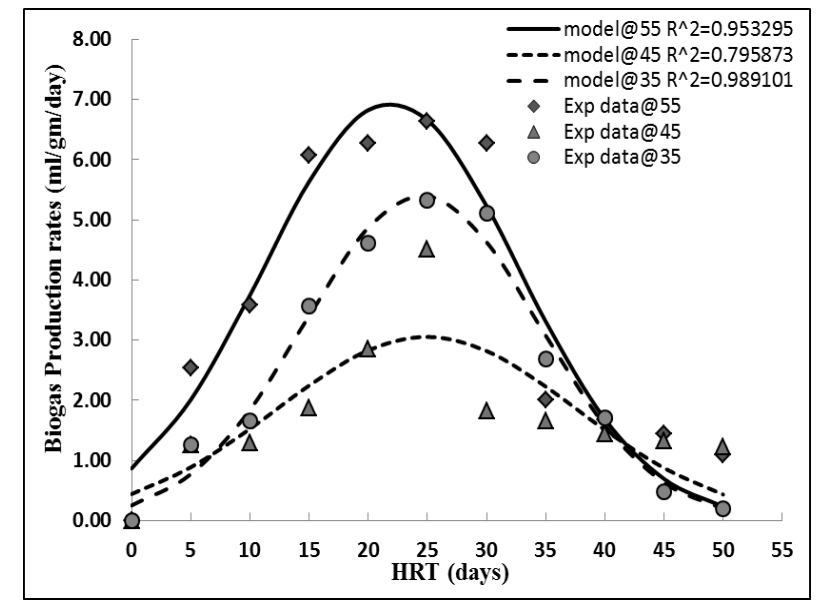

Fig. 4 Gaussian plot of biogas production rates from saw dust and cattle dung mixture at $55^{\circ} \mathrm{C}, 45^{\circ} \mathrm{C}$ and $35^{\circ} \mathrm{C}$ temperatures including both ascending and descending limb

\section{MODELLING}

Fig. 3(a) and 3(b) shows the linear plots of biogas production rates from saw dust and cattle dung mixture at three different temperatures $\left(55^{\circ} \mathrm{C}, 45^{\circ} \mathrm{C}\right.$ and $\left.35^{\circ} \mathrm{C}\right)$. Coefficient of determination, $\mathrm{R} 2$ of all the conditions in the in the ascending and descending limb ranged from 0.774 to 0.989. in the same manner Fig. 3(c) and 3(d) shows the exponential plot of biogas production rates from saw dust and cattle dung mixture at three different temperatures $\left(55^{\circ} \mathrm{C}, 45^{\circ} \mathrm{C}\right.$ and $\left.35^{\circ} \mathrm{C}\right) . \mathrm{R} 2$ of the feedstock at the three temperatures in the ascending and descending limb ranged from 0.967 to 0.995 which is found to be slightly better simulation than that of the linear regression. In case of Gaussian plot (Fig.4), the coefficient of determination, R2 was the highest in case of biogas production at $35^{\circ} \mathrm{C}(0.989)$ followed by biogas production at $55^{\circ} \mathrm{C}(0.953)$ and $45^{\circ} \mathrm{C}$ (0.795) respectively. This signifies that Gaussian plot of biogas production rates is ideal for the biogas production at $35^{\circ} \mathrm{C}$.

Coming to the cumulative biogas production simulation, modified Gompertz plot (0.998-0.999) and Logistic growth plot (0.997-0.999) showed better coefficient of determination, $\mathrm{R} 2$ than that of the exponential rise to maximum plot(0.977-0.988) as shown in Fig.5(a), 5(b) and 5(c). In exponential rise to maximum first order kinetic constant $(\mathrm{k})$ is found to be in the order of biogas production at $55^{\circ} \mathrm{C}(0.0130)>$ biogas production at $45^{\circ} \mathrm{C}(0.003)>$ biogas production at $35^{\circ} \mathrm{C}(0.004)$. Whereas the cumulative biogas production was in the order of biogas production at $55^{\circ} \mathrm{C}$ $(37.57 \mathrm{ml} / \mathrm{gm})>$ biogas production at $35^{\circ} \mathrm{C} \quad(26.57$ $\mathrm{ml} / \mathrm{gm})>$ biogas production at $45^{\circ} \mathrm{C}(19.24 \mathrm{ml} / \mathrm{gm})$. In modified Gompertz equation, the biogas production potential (A) was found to be in the order of biogas production at $55^{\circ} \mathrm{C}(39.10 \mathrm{ml} / \mathrm{gm})>$ biogas production at $35^{\circ} \mathrm{C}(28.33 \mathrm{ml} / \mathrm{gm})>$ biogas production at $45^{\circ} \mathrm{C}(20.64$ $\mathrm{ml} / \mathrm{gm})$. Biogas production rate $(\mu \mathrm{m})$ and lag phase period $(\lambda)$ is found to be $1.40 \mathrm{ml} / \mathrm{gm} /$ day and 6.22 day at $55^{\circ} \mathrm{C}$, $0.6134 \mathrm{ml} / \mathrm{gm} /$ day and 7.19 day at $45^{\circ} \mathrm{C}, 1.09 \mathrm{ml} / \mathrm{gm} /$ day and 9.15 day at $35^{\circ} \mathrm{C}$ respectively. In the Logistic growth equation the kinetic rate constant is found to be in the order of biogas production at $35^{\circ} \mathrm{C}(0.1716)>$ biogas production at $55^{\circ} \mathrm{C}(0.1610)>$ biogas production at $45^{\circ} \mathrm{C}(0.1412)$. Whereas the cumulative biogas production was in the order of biogas production at $55^{\circ} \mathrm{C} \quad(37.57 \mathrm{ml} / \mathrm{gm})>$ biogas production at $35^{\circ} \mathrm{C}(26.57 \mathrm{ml} / \mathrm{gm})>$ biogas production at $45^{\circ} \mathrm{C}(19.24 \mathrm{ml} / \mathrm{gm})$

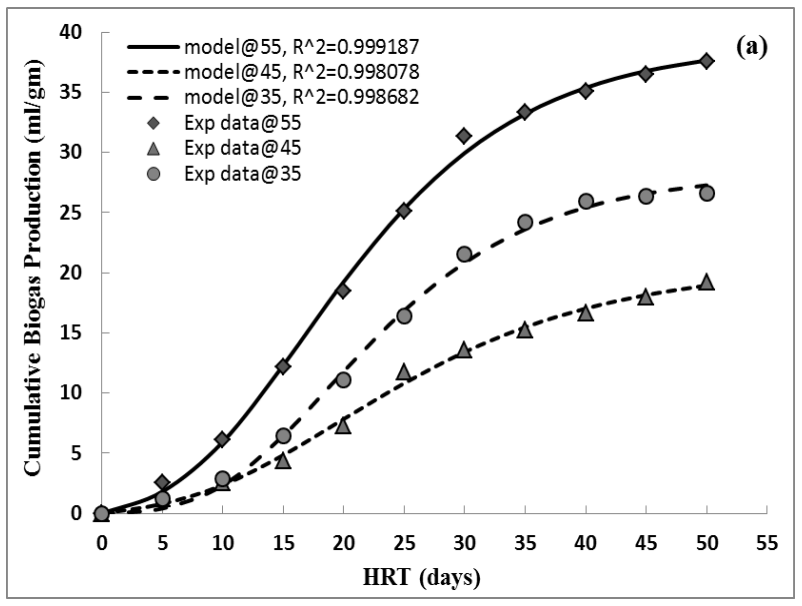

(a)

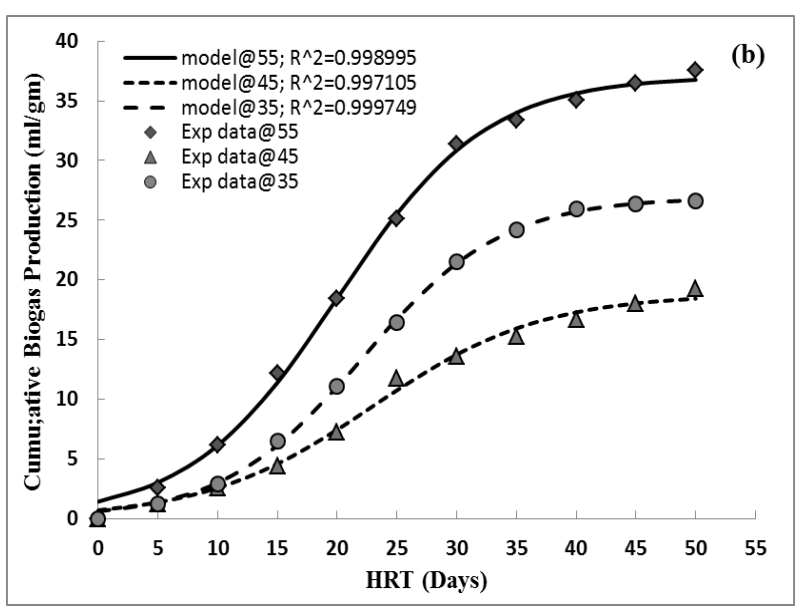

(b) 


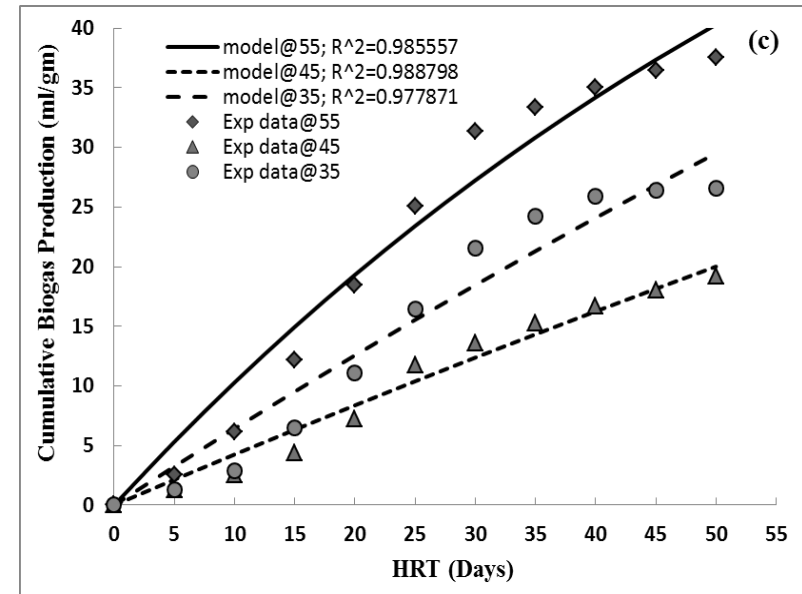

(c)

Fig. 5 (a) Modified Gompertz plots, (b) Logistic growth plot and (c) Exponential rise to maximum plot of cumulative biogas production from saw dust and cattle dung mixture at $55^{\circ} \mathrm{C}, 45^{\circ} \mathrm{C}$ and $35^{\circ} \mathrm{C}$ temperatures

\section{CONCLUSIONS}

The most important conclusion that can be drawn from this research is that with increase in temperature both maximum biogas production rate and biogas production potential can be improved. At the same time minimum time required for biogas production can also be reduced with increate in temperature of digestate. Temperature improves the production as well as the efficiency of the digester. Exponential plot simulated biogas production rate better than that of linear plot both in rising and falling limb. Gaussian plot was better simulated for biogas production at $35^{\circ} \mathrm{C}$ and $55^{\circ} \mathrm{C}$. Modified Gompertz plot and Logistic growth plot both had higher correlation than exponential rise to maximum plot for simulating cumulative biogas production.

\section{REFERENCES}

[1] Budiyono, Widiasa IN, Johari S, Sunarso. The kinetic of biogas production rate from cattle manure in batch mode. International Journal of chemical and biological Engineering 2010; 3(1): 39-44.

[2] Carlos V, John B. Anaerobic Digestion of Laminariadigitata: The effect of temperature on biogas production and composition. Waste Biomass Valor 2013; 4: 509-515.

[3] Das Ghatak, M., Mahanta, P.: Biogas production from lignocellulosic biomasses. Proceedings of the 22nd National and 11th International ISHMTASME Heat and Mass Transfer Conference, organized by IIT Kharagpur, India, 28th to 31st Dec'2013.

[4] De Gioannis G, Muntoni A, Cappai G, Milia S. Landfill gas generation after mechanical biological treatment of municipal solid waste. Estimation of gas generation rate constants. Waste Manage 2009; 29:1026-1034.
[5]

[6]

Garba B. Effect of temperature and retention period on biogas production from lignocellulosic material. Renewable Energy 1996; 9: 938-941.

Hamdi M., Effects of agitation and pretreatment on the batch anaerobic digestion of olive mil, Bioresource Technology, Volume 36, Issue 2, 1991, Pages 173-178.

Hashimoto A.G., Varel V. and Chen Y.R., Ultimate methane yield from beef cattle manure: effect of temperature, ration constitutes, antibiotics and manure age, Journal of agricultural wastes, vol. 3 (1981), pp. 241.

Hills, D.J., and Roberts, D. W., 1981.“Anaerobic digestion of dairy manure and field crop residues". Agricultural Wastes, 3, pp. 179-189.

Kumar, S., Mondal, A.N., Gaikward, S.A., Devotta, S., Singh, R.N., 2004. Qualitative assessment of methane emission inventory from municipal solid waste disposal sites: a case study. Atmos. Environ.

38, 4921-4929. 2006. "Laboratory Investigations on co-digestion of Energy Crops and Crop Residues with Cow manure for Methane Production: Effect of Crop to Manure Ratio". Resources, Conservation and Recycling, 51, pp.591-609.

[11] LequericaJL, Valles $\mathrm{S}$ and Flors A., 1984. "Kinetics of rice straw methane fermentation". Applied Microbiology Biotechnology, 19, pp.7074.

[12] Lo, H.M., T.A. Kurniawan, M.E.T. Sillanpaa, T.Y.Pai and C.F. Chiang et al.,2010. Modelling biogas production from organic fraction of MSW co-digested with MSWI ashes in anaerobic bioreactors. Bio resources Technology, vol. 101, pp. 6329-6335.

[13] Mahanta, P., Saha, U.K., and Kalita, P., 2004. "The influence of temperature and total solid concentration on the gas production rate of a biogas digester". Journal of Energy in Southern Africa, 15, pp. 112-117.

[14] Nopharatana, A., P. C. Pullammanappalli, and W. P. Clarke, 2007. "Kinetics and dynamic modelling of batch anaerobic digestion of municipal solid waste in a stirred reactor". Waste Management,27, pp. 595-603.

[15] Somayaji, D., and Khanna, S., 1994. "Biomethanation of rice and wheat straw". World Journal of Microbiology and Biotechnology, 10, pp. 521-523.

[16] Usman, M.A., Olanipekun, O.O., Ogunbanwo, O.A.: Effect of temperature on Biogas production from lignocellulosic substrate. International Journal of Research in Chemistry and Environment, 2, 6871 (2012).

[17] Varel V., Hashimoto A.G., and Chen Y.R., effect of temperature and retention time on methane production from cattle waste, applied Envir. Microbiol., vol. 40 (1980), pp. 217. 
[18] Yusuf, M.O.L., Debora, A., Ogheneruona, D.E.: Ambient temperature kinetic assessment of biogas production from co-digestion of horse and cow dung. Res. Agr. Eng., 57(3), 97-104 (2011). 